\title{
Oestrogen receptors and protein synthesis in caruncular and intercaruncular endometrium of sheep before implantation
}

\author{
J. K. Findlay, I. J. Clarke, J. Swaney, Noelene Colvin and B. Doughton \\ Medical Research Centre, Prince Henry's Hospital, St Kilda Road, Melbourne, Victoria 3004, \\ Australia
}

\begin{abstract}
Summary. The rate of protein synthesis was higher in caruncular $(P<0.05)$ and intercaruncular endometrium $(P<0.01)$ of pregnant compared to non-pregnant ewes on Day 11 (Day $0=$ day of oestrus), but not on Days 9,13 and 15. Cytosolic oestrogen receptor concentrations ( $\mathrm{nmol} / \mathrm{mg}$ protein) were lower in caruncular endometrium of pregnant ewes than in non-pregnant ewes on Days $9(P<0.02), 13$ $(P<0.05)$ and $15(P<0.001)$ but not on Day 11 . In intercaruncular endometrium, the receptor values were lower on Day $15(P<0.02)$ of pregnancy compared to non-pregnancy, but not on the other days. The dissociation constant $(0.75-2.55 \times$ $10^{-10} \mathrm{M}$ ) of oestradiol-17 $\beta$ for cytosolic receptors was similar in both tissues, regardless of pregnancy status or day of sampling. The rate of protein synthesis was generally higher in intercaruncular endometrium whereas cytosol receptor concentrations were higher in caruncular endometrium. When the blastocyst was confined to one uterine horn on Day 2 in another group of ewes, there was a decrease in nuclear $(P>0.05)$, cytosolic $(P<0.05)$ and total $(P<0.05)$ oestrogen receptors only in caruncular endometrium in the pregnant horn on Day 15. There were no differences in the proportions of receptors localized in nuclear fractions or in the rate of protein synthesis in either endometrial tissue from the pregnant or the non-pregnant horn. We conclude that the ovine blastocyst is capable of influencing oestrogen receptor levels in caruncular and intercaruncular endometrium by a local action as early as Day 9, well before endocrine recognition of pregnancy on Day 12 and attachment on Day 15.
\end{abstract}

\section{Introduction}

The developing ovine blastocyst is increasingly dependent on its uterine environment before implantation and the need for changing endometrial function during this period has been demonstrated in embryo transfer studies (Rowson \& Moor, 1966; Lawson \& Findlay, 1977). Endometrial function can change as a result of the influence of ovarian steroids and the blastocyst during the pre-implantation period (Findlay, 1981).

In sheep, the first close contact between the trophoblast and uterine epithelium occurs on Day 14 (Day $0=$ day of oestrus), but morphological changes within the epithelium are not apparent until Day 15, the day of implantation (Boshier, 1969). The presence of a blastocyst on or before Day 15 is associated with changes in the rate of protein synthesis (Findlay et al., 1981) and in prostaglandin (PG) F-2 $\alpha$ and PGE-2 content and concentration in the endometrium (Lewis et al., 1977; Lewis, Jenkins, Fogwell \& Inskeep, 1978; Ellinwood, Nett \& Niswender, 
1979; Findlay et al., 1981). Furthermore, uterine flushings collected on or before Day 15 of pregnancy contain higher levels of protein (Roberts, Parker \& Symonds, 1976; Ellinwood et al., 1979), PGF-2 $\alpha$ and PGE-2 (Ellinwood $e t$ al., 1979), glycosidase activity (Roberts et al., 1976) and pregnancy-associated antigen (Staples, Lawson \& Findlay, 1978) than do those from non-pregnant ewes.

Whilst it is possible that some of the proteins in the uterine lumen originate from the blastocyst, it is also possible that much of the luminal protein found during the preimplantation period is of endometrial origin, stimulated by a local or systemic action of the blastocyst on endometrial protein synthesis. Caruncular and intercaruncular endometrium show significant increases in protein synthesis on Day 15 of pregnancy (Findlay et al., 1981). We have now compared the levels of protein synthesis by caruncular and intercaruncular endometrium of pregnant and non-pregnant ewes and investigated the possible role of oestradiol-17 $\beta$ in endometrial function during the preimplantation period (Findlay, 1981).

\section{Materials and Methods}

\section{Animals}

Parous Corriedale ewes were run with vasectomized or intact rams fitted with marking harnesses and checked daily for mating marks indicative of oestrus. The ewes were penned without food or water on the day before surgery. Blood samples for progesterone were taken from the jugular vein by venepuncture on the day before, and on the morning of surgery. Laparotomy was performed under anaesthesia, induced with thiopentone sodium (Intraval sodium: May \& Baker, Melbourne) and maintained with halothane (ICI, Meibourne). All animals were given $500 \mathrm{mg}$ dihydrostreptomycin (Streptopen: Glaxovet, Melbourne) daily for $1-2$ days after surgery.

\section{Experiment 1}

The aim was to determine the rate of protein synthesis and the concentration of cytosolic oestrogen receptors in the caruncular and intercaruncular endometrium of pregnant and non-pregnant ewes on Days 9, 11, 13 and $15(\mathrm{~N}=5-6 /$ group $)$.

The reproductive tract of each ewe was exposed at laparotomy and the number and appearance of corpora lutea in the ovary were recorded. A bowel clamp was then placed on or below the cervix. The uterine lumen was flushed by injection of $20 \mathrm{ml}$ Medium 199 (C.S.L., Melbourne) containing indomethacin ( $1 \mu \mathrm{g} / \mathrm{ml}$; Indocid, M.S.D., Melbourne) and penicillin (50 $\mathrm{U} / \mathrm{ml}$; Crystopen: Glaxovet, Melbourne), into the lumen of the uterine horn contralateral to the corpus luteum. The tract was gently massaged to force the fluid out through a glass cannula (6 $\mathrm{mm}$ o.d.; $5 \mathrm{~mm}$ i.d.) inserted near the uterotubal junction on the side of the corpus luteum. Blastocysts were removed from the flushing medium which was then centrifuged $(2000 \mathrm{~g}, 10$ $\min$ ) at $4^{\circ} \mathrm{C}$ and the supernatant was stored at $-15^{\circ} \mathrm{C}$. The reproductive tract was removed, opened longitudinally and the caruncles dissected from the intercaruncular endometrium within $20 \mathrm{~min}$. Tissue samples were kept on ice in $10 \mathrm{~mm}$-Tris- $\mathrm{HCl}$ buffer, $\mathrm{pH} 7.6$, containing 1.5 mM-EDTA and 1 mM-dithiothreitol for cytosolic oestrogen receptors, or in Medium 199 containing penicillin $(50 \mathrm{U} / \mathrm{ml})$ for measuring protein synthesis.

\section{Experiment 2}

The aim was to determine whether the blastocyst exerted a local or systemic influence on the rate of protein synthesis and on the concentration of cytosolic and nuclear oestrogen receptors in caruncular and intercaruncular endometrium of ewes on Day 15. 
Ewes underwent laparotomy on Day 2 after fertile mating. Connective tissue between the two uterine horns was separated by blunt dissection down to the level of the bifurcation. The uterine horn contralateral to the ovary containing the corpus luteum was ligated at the uterotubal junction and was done at random in animals with corpora lutea in both ovaries. One uterine horn was also ligated at the level of the bifurcation, leaving the blastocyst either separated from $(\mathrm{N}=8)$ or accessible to $(\mathrm{N}=15)$ the cervical end of the uterus. Two ties, approximately $5 \mathrm{~mm}$ apart, were placed around the horn at the point of ligature so that the major uterine blood vessels were not occluded. The horn was transected between the ties through to the lumen. The reproductive tract was smeared liberally with surgical jelly (KY, Johnson \& Johnson, Sydney) to prevent adhesions before it was returned to the abdominal cavity.

On Day 15, the reproductive tract was re-exposed and the contents of the lumen were flushed from each uterine horn with $10 \mathrm{ml}$ Medium 199. The tissues were harvested as described in Exp. 1, except that for analysis of nuclear oestrogen receptor tissues were placed in $0 \cdot 1$ M-sodium phosphate buffer, $\mathrm{pH} 7.3$, containing $0.25 \mathrm{M}$-sucrose and $1 \mathrm{~mm}$-mercaptoethanol. Oestrogen receptor concentrations were measured in tissues of 3 ewes, whilst the rate of protein synthesis was measured in tissues of 8 ewes. For comparison, nuclear and cytosolic oestrogen receptor concentrations were measured in endometrial tissue from 4 non-pregnant ewes which had not undergone surgery on Day 2.

\section{Protein synthesis}

The rate of protein synthesis in caruncular and intercaruncular endometrium and blastocysts (Exp. 2 only) was estimated by the incorporation of $\mathrm{L}-\left[3,4,5-{ }^{3} \mathrm{H}\right]$ leucine (sp. act. $5 \cdot 18$ $\mathrm{TBq} / \mathrm{mmol}$; NEN, Boston, U.S.A.) into trichloroacetic acid-insoluble protein (Findlay et al., $1981)$ using the modification of Gottesman (1978). Protein content was measured by the method of Lowry, Rosebrough, Farr \& Randall (1951).

\section{Oestrogen receptors}

Tissues for analysis were processed immediately after collection. All procedures were carried out at $4{ }^{\circ} \mathrm{C}$ unless otherwise indicated. The tissues were washed in buffer, weighed and homogenized in 5 volumes of the appropriate assay buffer (see below). In Exp. 1 these homogenates were centrifuged at $105000 \mathrm{~g}_{\mathrm{av}}$. for $1 \mathrm{~h}$ at $4^{\circ} \mathrm{C}$. The supernatant was removed and stored at $-20^{\circ} \mathrm{C}$ until assay without significant losses of receptors over 3-4 months. On the day of assay the samples were thawed and diluted to approximately $1 \mathrm{mg}$ protein $/ \mathrm{ml}$. Aliquots (200 $\mu \mathrm{l})$ of this cytosol were then added to duplicate tubes containing $100 \mu \mathrm{l} 9 \mathrm{nM}-\left[{ }^{3} \mathrm{H}\right]$ oestradiol- $17 \beta$ (sp. act. $4.07 \mathrm{TBq} / \mathrm{mmol} ; \mathrm{NEN}) \pm 100$-fold excess of diethylstilboestrol (Steraloids, Wilton, U.S.A.) for saturation analysis of binding capacity. This concentration of ligand is one close to saturation for oestrogen receptors and Scatchard analysis indicated a single class of binding sites (Text-fig. 1). Incubation of cytosol at $27^{\circ} \mathrm{C}$ resulted in some receptor loss (Text-fig. 2) so all subsequent assays were incubated overnight at $4^{\circ} \mathrm{C}$, which allowed the reaction to come to equilibrium (Text-fig. 2). Separation of bound from free steroids was by LH-20 Sephadex chromatography (Ginsburg, Greenstein, MacLusky, Morris \& Thomas, 1974). The relative binding affinities $(\%$; oestradiol $-17 \beta=100)$ of various steroids for oestrogen receptor in the cytosolic fraction of the endometrium were as follows: diethylstilboestrol, 143; oestrone, 17; oestradiol-17 $\alpha$, 16; oestriol, 14; progesterone, testosterone, androstenedione, 5 $\alpha$-dihydrotestosterone and cortisol, $<0.01$.

One ewe from each of the pregnant and non-pregnant groups on each day of sampling was selected for a study of oestrogen receptor affinity in caruncular and intercaruncular endometrium. Duplicate aliquots of cytosol were incubated with 0.03 to $6.0 \mathrm{nM}-\left[{ }^{3} \mathrm{H}\right]$ oestradiol \pm 100 -fold excess diethylstilboestrol, and the results were analysed by the method of Scatchard (1949). 


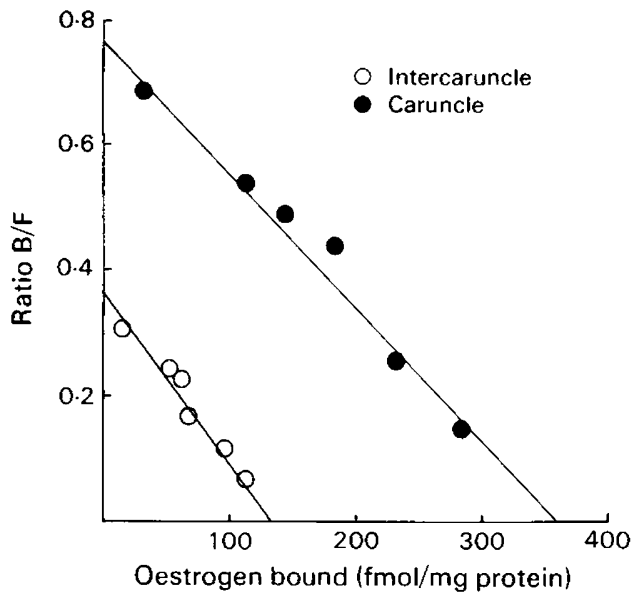

Text-fig. 1. Scatchard analysis of binding in cytosolic preparations from caruncular and intercaruncular endometrium of a non-pregnant ewe on Day 11. Duplicate aliquots of cytosol were incubated overnight at $4^{\circ} \mathrm{C}$ with $0.03-1 \mathrm{nM}$ - $\left.{ }^{3} \mathrm{H}\right]$ oestradiol \pm 100 -fold excess diethylstilboestrol; bound and free steroid were separated by LH-20 Sephadex chromatography. Caruncular endometrium; $K_{\mathrm{d}}=2.3 \times 10^{-10} \mathrm{M}, n_{\max }=359 \mathrm{fmol} / \mathrm{mg}$ protein, $r=-0.98$ : intercaruncular endometrium; $K_{\mathrm{d}}=2.0 \times 10^{-10} \mathrm{M}, n_{\max }=146 \mathrm{fmol} / \mathrm{mg}$ protein, $r=-0.95$ (Linear regression analysis).

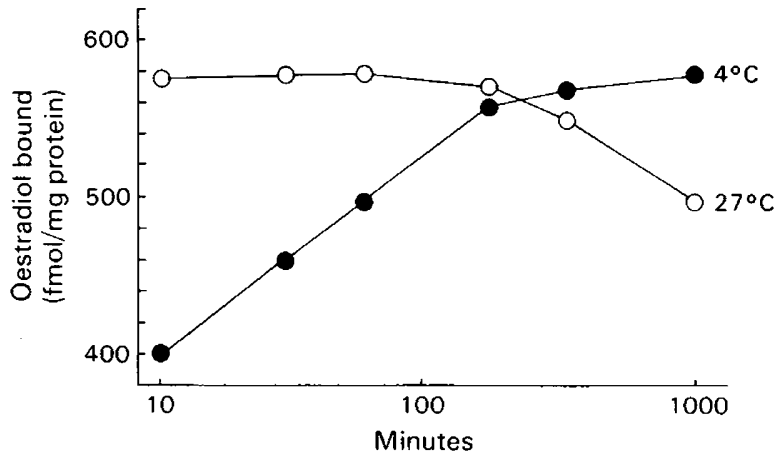

Text-fig. 2. Effect of time and temperature of incubation on the specific binding $\left[{ }^{3} \mathrm{H}\right.$ loestradiol ( $3 \mathrm{nM}$ ) in cytosolic preparations of caruncular endometrium of a non-pregnant ewe. Each point represents the mean of triplicate determinations.

In Exp. 2, cytosolic and nuclear oestrogen receptor concentrations were measured by saturation analysis. Fresh tissues were weighed, homogenized in 5 volumes of buffer, and centrifuged at $800 \mathrm{~g}$. The supernatant was then re-centrifuged at $105000 \mathrm{~g}_{\mathrm{av}}$ for $1 \mathrm{~h}$ at $4^{\circ} \mathrm{C}$ and used for determination of cytosolic receptors as above. The $800 \mathrm{~g}$ pellet was processed immediately according to the nuclear exchange method of Roy \& McEwen (1977), modified for ovine pituitary tissues (Clarke, Burman, Funder \& Findlay, 1981) and validated for ovine uterine tissues. Nuclear $\mathrm{KCl}$ extracts had to be incubated for $6 \mathrm{~h}$ at $27^{\circ} \mathrm{C}$ to give complete exchange (Text-fig. 3). Aliquots of nuclear extracts and whole homogenates were taken for DNA measurement to determine procedural losses of nuclear oestrogen receptors. Receptor number was then expressed per $\mathrm{g}$ wet weight.

Protein content was measured by the method of Bradford (1976) and DNA content by the method of Burton (1956). 


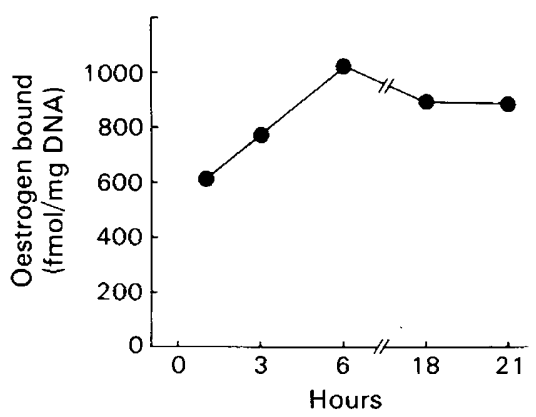

Text-fig. 3. Time course of exchange in a nuclear oestrogen receptor extract from caruncular endometrium of a non-pregnant ewe. The extracts were incubated in triplicate in the presence of $3 \mathrm{nM}-\left[{ }^{3} \mathrm{H}\right]$ oestradiol \pm 100 -fold excess of diethylstilboestrol; each point represents mean specific binding.

\section{Progesterone radioimmunoassay}

The progesterone radioimmunoassay (Hossain, Lee, Clarke \& O'Shea, 1979) had a within-assay and between-assay coefficient of variation of 5.9 and $11.8 \%$ respectively, and a sensitivity of $15.5 \mathrm{fmol} /$ tube. Assay buffer, hexane and wether plasma blanks contained $<0.2$ $\mathrm{nmol} / \mathrm{l}$. The values were not corrected for methodological losses ( $>75 \%$ recovery).

\section{Results}

\section{Experiment 1: plasma progesterone}

The plasma progesterone levels (mean \pm s.e.m.; $\mathrm{nmol} / \mathrm{l}$ ) in the pregnant ewes were $6.68 \pm$ 1.11 on Day $8,5.28 \pm 0.31$ on Day $9,4.64 \pm 0.54$ on Day $10,6.30 \pm 0.92$ on Day $11,5.02 \pm$ 0.67 on Day $12,5.66 \pm 1 \cdot 27$ on Day $13,6 \cdot 23 \pm 1.02$ on Day 14 and $5 \cdot 25 \pm 0.86$ on Day 15 .

\section{Experiment 1: protein synthesis}

Effect of pregnancy. Significantly more leucine was incorporated into acid-insoluble protein in pregnant than in non-pregnant caruncular $(t=3.05$, d.f. $=8, P<0.05)$ and intercaruncular $(t=4.62$, d.f. $=8, P<0.01$ ) endometrium on Day 11, but not on any other days tested (Text-fig. 4).

Caruncular and intercaruncular endometrium. The incorporation of leucine into protein was higher in intercaruncular than caruncular endometrium of non-pregnant ewes on Days $9(t=$ 5.09 , d.f. $=4, P<0.01)$ and $11(t=3 \cdot 79$, d.f. $=4, P<0.05)$ and of pregnant ewes on Day 11 $(t=5.61$, d.f. $=4, P<0.01$ ) (Text-fig. 4).

Effect of time after mating. Leucine incorporation into intercaruncular endometrium of pregnant ewes increased from Day 9 to Day 11 and decline thereafter, such that the levels on Day 11 were higher than on Days 9,13 and $15(P<0.01)$. There was no significant change in either endometrial tissue in non-pregnant ewes or in caruncular endometrium of pregnant ewes (Text-fig. 4).

\section{Experiment 1: oestrogen receptors}

Effect of pregnancy. Cytosolic receptor concentrations were significantly lower (independent $t$ test) in pregnant than in non-pregnant caruncular endometrium on Days $9(t=3 \cdot 31$, d.f. $=7, P$ $<0.02), 13(t=2.44$, d.f. $=8, P<0.05)$ and $15(t=7.85$, d.f. $=11, P<0.001)$ but not on Day 11 (Text-fig. 5). Although concentrations of cytosolic receptors were lower in 


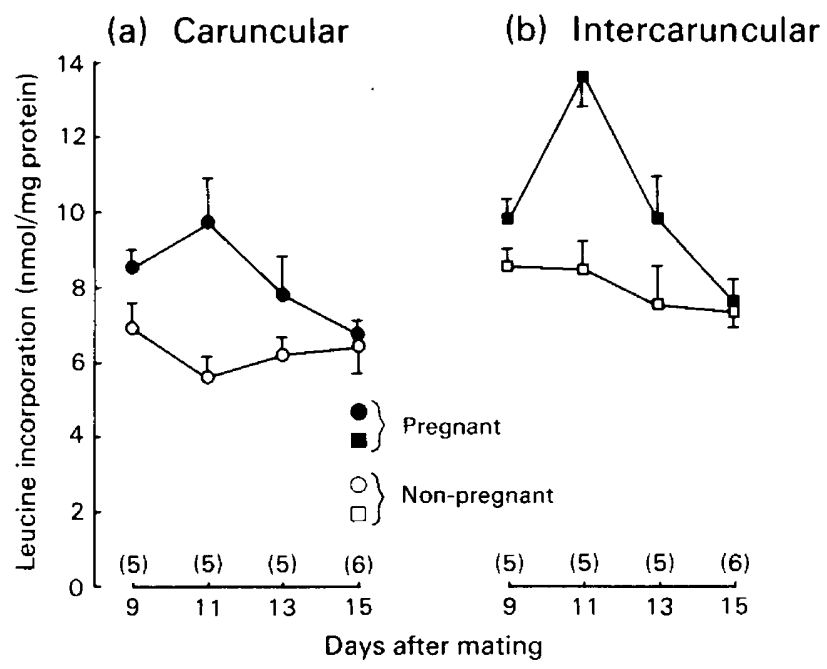

Text-fig. 4. Rate of incorporation of radiolabelled leucine into acid-insoluble protein in vitro by (a) caruncular and (b) intercaruncular endometrium of pregnant and non-pregnant ewes. Values are mean \pm s.e.m. for the number of ewes indicated in parentheses.

(a) Caruncular

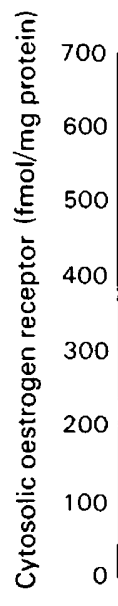

(b) Intercaruncular 
were higher on Day 9 compared with Days 13 and $15(P<0.01)$ but not Day 11 . In tissue from non-pregnant ewes, the oestrogen receptor levels on Days 9 and 15 were higher than on Day 13 in caruncular $(P<0.01)$ and intercaruncular $(P<0.05)$ tissues (Text-fig. 5). In addition, the levels in non-pregnant caruncular tissue on Day 11 were lower $(P<0.01)$ than those on Days 9 and 15 .

Receptor affinity. The apparent dissociation constant $\left(\times 10^{-10} \mathrm{M}\right)$ ranged from 0.75 to 2.55 (geometric mean 1.33) with no differences between tissue type, pregnancy status or day of sampling.

\section{Experiment 2: unilateral pregnancy}

Healthy blastocysts were recovered on Day 15 from $8 / 23$ ewes made unilaterally pregnant; in $6 / 15$ ewes the blastocyst had access to the cervical end of the uterus and in $2 / 8$ ewes the blastocyst did not have access. The blastocysts were judged to be healthy by size (Bindon, 1971a) and translucent appearance and by the rate of incorporation of leucine into acid-insoluble protein (see below). A further 7 ewes had degenerating blastocysts and these animals were rejected and in 8 ewes no blastocyst or remnants were recovered. Three of the 8 ewes had bilateral ovulations and 5 had a single ovulation ipsilateral to the blastocyst. The mean ( \pm s.e.m.) peripheral concentrations of progesterone on Days 14 and 15 were $10.02 \pm 0.54 \mathrm{nmol} / 1$ and $11.03 \pm 1.62 \mathrm{nmol} / \mathrm{l}$, respectively and all values were $>6.4 \mathrm{nmol} / 1$.

\section{Experiment 2: protein synthesis}

The mean rate of incorporation of leucine into acid-insoluble protein was similar in endometrial tissues of ewes with unilateral pregnancy on Day 15 (Table 1) and control ewes on Day 15 (Text-fig. 4). The rates of protein synthesis were similar in both endometrial tissues in both horns of ewes made unilaterally pregnant (Table 1) and were not influenced by the incidence of ovulation (bilateral or unilateral). The mean ( \pm s.e.m.) rate of incorporation of leucine into acid-insoluble protein by 6 blastocysts recovered from 6 ewes made unilaterally pregnant was $39.11 \pm 5.48 \mathrm{nmol} / \mathrm{mg}$ protein, the same range as previously reported (Findlay $e t$ al., 1981).

Table 1. The mean \pm s.e.m. levels of oestrogen receptor and rate of leucine incorporation into acidinsoluble protein on Day 15 in caruncular and intercaruncular endometrium of non-pregnant control ewes and of ewes with the blastocyst confined surgically to one uterine horn (unilaterally pregnant)

\begin{tabular}{|c|c|c|c|c|c|c|c|}
\hline \multirow[b]{2}{*}{ Group } & \multirow[b]{2}{*}{ Status } & \multirow{2}{*}{$\begin{array}{l}\text { Endometrial } \\
\text { tissue }\end{array}$} & \multicolumn{4}{|c|}{ Oestrogen receptor $(\mathrm{pmol} / \mathrm{g}$ wet $\mathrm{wt})$} & \multirow{2}{*}{$\begin{array}{c}\text { Leucine } \\
\text { incorp. } \\
\text { (nmol } / \mathrm{mg} \\
\text { protein) }\end{array}$} \\
\hline & & & Nuclear & Cytosol & Total & Nuclear (\%) & \\
\hline \multirow[t]{2}{*}{ Control } & Non- & Caruncle & $2.08 \pm 0.98$ & $22 \cdot 34 \pm 7 \cdot 20$ & $24.42 \pm 8.08$ & $7 \cdot 6 \pm 2 \cdot 6$ & - \\
\hline & & $\begin{array}{l}\text { Inter- } \\
\text { caruncle }\end{array}$ & $1.41 \pm 0.51$ & $8 \cdot 28 \pm 1.45$ & $9 \cdot 69 \pm 2.00$ & $13 \cdot 1 \pm 2 \cdot 7$ & - \\
\hline \multirow[t]{4}{*}{ Unilateral } & $\begin{array}{l}\text { Non- } \\
\text { pregnant }\end{array}$ & Caruncle & $1.21 \pm 0.11$ & $26.89 \pm 2.55^{*}$ & $28 \cdot 10 \pm 2 \cdot 58 \dagger$ & $4.4 \pm 0.4$ & $7.27 \pm 1.72$ \\
\hline & & $\begin{array}{l}\text { Inter- } \\
\text { caruncle }\end{array}$ & $0.80 \pm 0.69$ & $11.01 \pm 1.17$ & $11 \cdot 81 \pm 1 \cdot 22$ & $6 \cdot 8 \pm 0.4$ & $8.68 \pm 2.01$ \\
\hline & Pregnant & Caruncle & $0.70 \pm 0.18$ & $15 \cdot 34 \pm 3 \cdot 02^{*}$ & $16.03 \pm 2.83 \dagger$ & $5 \cdot 2 \pm 2 \cdot 2$ & $6.91 \pm 2.08$ \\
\hline & & $\begin{array}{l}\text { Inter- } \\
\text { caruncle }\end{array}$ & $0.55 \pm 0.15$ & $6 \cdot 83 \pm 2 \cdot 54$ & $7 \cdot 38 \pm 2.49$ & $9 \cdot 2 \pm 5 \cdot 5$ & $10 \cdot 9 \pm 2 \cdot 40$ \\
\hline
\end{tabular}

$\dagger^{*}$ Significantly different values by $t$ test $(P<0.05)$. 


\section{Experiment 2: oestrogen receptors}

In caruncular tissue oestrogen receptor concentration was higher in the nuclear, cytosolic ( $t$ $=3.30$, d.f. $=4, P<0.05)$ and total $(t=3 \cdot 15$, d.f. $=4, P<0.05)$ fractions in the non-pregnant than in the pregnant horn of ligated uteri, although the difference in nuclear receptor values was not significant $(t=2 \cdot 14$, d.f. $=4,0.05<P<0 \cdot 1)$ (Table 1$)$. Receptor values in these fractions from intercaruncular tissue showed a similar trend but the differences were not significant (Table 1). There were no significant differences $(P>0.05)$ in the proportion of receptors localized in the nuclear fractions compared to total receptors in the various groups (Table 1). Cytosolic and total oestrogen receptors in caruncular were higher $(P<0.05)$ than in intercaruncular endometrium. The concentrations of oestrogen receptors in the cytosolic and nuclear fractions of caruncular and intercaruncular tissues from the non-pregnant horn of the unilaterally pregnant ewes did not differ significantly $(P>0.05)$ from those in non-pregnant control ewes (Table 1$)$.

\section{Discussion}

This study demonstrates that the presence of a blastocyst is associated with a transient increase in protein synthesis on Day 11, and a decrease in oestrogen receptor levels as early as Day 9 in endometrial tissue of the ewe. The changes in oestrogen receptors appeared to result from a local rather than systemic action of the blastocyst and the effects were confined mainly to caruncular endometrium. In both experiments, the concentrations of receptors were approximately 2-fold higher in caruncular compared to intercaruncular endometrium, irrespective of pregnancy status. This difference in the localization of oestrogen receptors is consistent with the observation that caruncular endometrium contained 2- to 3 -fold higher concentrations of oestradiol-17 $\beta$ than the remaining uterine tissue (Challis, Louis, Robinson \& Thorburn, 1976). Miller, Murphy \& Stone (1977) noted no significant difference between cytosolic oestrogen receptor concentrations in caruncular endometrium and whole uterine tissue, but they did not compare the two endometrial tissues.

We confirmed that up to Day 13 of the oestrous cycle there is a decline in uterine cytosolic oestrogen receptors in non-pregnant ewes (Miller et al., 1977; Koligian \& Stormshak, 1977a). A similar pattern of decline in cytosolic receptors was observed in caruncular endometrium of pregnant ewes up to Day 13, although the overall concentrations were lower than in non-pregnant ewes. The decline in oestrogen receptor up to Day 13 was most probably due to peripheral progesterone values (Koligian \& Stormshak, 1977b; Stone, Wild \& Miller, 1979; Miller, Wild \& Stone, 1979). By Day 15, oestrogen receptor concentration in uterine tissues of non-pregnant ewes. The decline in oestrogen receptors up to Day 13 was most probably due to trations would be substantially decreased and oestradiol values increased (see Findlay, 1981). (Unfortunately, the samples for plasma progesterone from the non-pregnant ewes were lost before assay.) In pregnant ewes cytoplasmic oestrogen receptor values were similar on Days 13 and 15 , reflecting similar progesterone levels.

The difference observed in cytosolic oestrogen receptor values from Days 9 to 15 between caruncular endometrium of pregnant and non-pregnant ewes is unlikely to have been due to an increase in local concentrations of oestradiol translocating more cytosolic receptors to the nucleus. Lack of evidence for a local increase in endometrial oestradiol content (see below) and decreased nuclear receptor concentrations on Day 15 in caruncular endometrium of the pregnant horn of unilaterally pregnant ewes support this suggestion. However, final verification awaits measurements of tissue concentrations of oestradiol and nuclear oestrogen receptor on other days of the cycle and pregnancy. In the pig, the trophoblast actively synthesizes oestrogen during the preimplantation period (Gadsby, Heap \& Burton, 1980), but endometrial oestrogen receptor concentrations do not differ between pregnant and non-pregnant sows (Deaver \& Guthrie, 1980). In contrast, increased concentrations of both nuclear receptors were observed on 
Day 6 in the implantation sites of the rat (Logeat, Sartor, Vu Hai \& Milgrom, 1980) although this observation has been disputed (Martel \& Psychoyos, 1981). In the rat, there is considerable controversy about the capacity of the blastocyst to synthesize oestrogen (Bullock, 1977). The decrease in oestrogen receptor in ovine caruncular tissue during pregnancy may be due to local increases in the concentration of progesterone. Although Bindon (1971b) observed that mean concentrations of peripheral progesterone of pregnant and non-pregnant ewes did not differ until Day 16, he did note a large (up to $50 \mathrm{nmol} / \mathrm{l}$ ), transient peak in plasma between Days 11 and 14. It is possible that the pregnant uterus might be a source of progesterone before implantation. The capacity of sheep trophoblast to synthesize progesterone before attachment has not been reported, although ovine trophoblast cells harvested on Day 20 can synthesize progesterone in vitro (Marcus, Ainsworth \& Lucis, 1979). Cow blastocysts obtained between Days 13 and 16 post coitum can also synthesize progesterone in vitro (Shemesh, Milaguir, Ayalon \& Hansel, 1979). Alternatively, sheep endometrium might synthesize and concentrate progesterone in the presence of a blastocyst, but this has not been reported.

The increase on Day 11 of protein synthesis in endometrium in the presence of a blastocyst could be the cause of the increased protein content in the lumen between Days 13 and 17 of pregnancy (Ellinwood et al., 1979) and the increased glycosidase activity in uterine flushings before attachment (Roberts et al., 1976). It could also be important for the antiluteolytic action of the blastocyst which must become effective before Day 12 (Moor, 1968; Martal, 1981). In a previous study (Findlay et al.. 1981), the presence of a blastocyst was associated with a small, but significant increase in protein synthesis in both areas of endometrium on Day 15. In this study, no such difference was observed in either experiment and explanations for this discrepancy are not apparent. There were differences in breed and geographical location of sheep and in the time of removal, handling and flushing of the tract. The rates of incorporation of leucine into acid-insoluble protein were in the same range in both studies.

The change in rates of protein synthesis in endometrium from non-pregnant ewes was similar to that described by Miller et al. (1977). That synthesis of protein in endometrium of non-pregnant ewes is under the control of ovarian steroids is now well established (Stone, Murphy \& Miller, 1978; Stone et al., 1979; Miller et al., 1979; Findlay et al., 1981). The blastocyst could increase endometrial protein synthesis on Day 11 by one of several mechanisms, including an effect on blood flow or by a local action of oestrogen. The increase occurred before the first detected increase in blood flow to the endometrium of pregnant ewes on Days 12-13 (Greiss \& Anderson, 1970; Greiss \& Miller, 1971), suggesting that this is unlikely. Although oestradiol-17$\beta$ can mimic the effects of pregnancy on endometrial protein synthesis (Stone et al., 1979; Miller et al., 1979; Findlay et al., 1981) and uterine blood flow (Huckabee, Crenshaw, Curet, Mann \& Barron, 1970) there is no conclusive evidence that this steroid is involved. Neither the trophoblast (Gadsby et al., 1980) nor the endometrium (Findlay et al., 1981) of sheep have the capacity to produce oestrogens before attachment. Furthermore, pregnancy can be maintained in ovariectomized, adrenalectomized ewes provided progesterone and a corticosteroid, but not oestrogen, are given exogenously (Cumming, Baxter \& Lawson, 1974).

It is possible that small, but as yet undetectable, quantities of oestrogen are synthesized locally in early pregnancy and are responsible for the increase in protein synthesis. The failure of such small quantities of oestrogen to stimulate an increase in oestrogen receptor concentration in endometrium during pregnancy could be explained by the presence of progesterone (Koligian \& Stormshak, 1977b; Stone et al., 1979; Miller et al., 1979). Whilst progesterone can decrease oestrogen receptors, it is without effect on oestradiol-induced protein synthesis, RNA : DNA ratio and enzyme activities in endometrial tissue of ovariectomized ewes (Stone et al., 1979; Miller et al., 1979; Findlay et al., 1981). This apparent discrepancy may reflect differences in the function of the two major cell types in the endometrium (McCormack \& Glasser, 1980), stromal cells predominantly in caruncular endometrium and epithelial cells predominantly in inter- 
caruncular endometrium (Huslig, Fogwell \& Smith, 1979). If oestrogen receptors are present in ovine stromal cells, as they are in the rat (Talley, Tobert, Armstrong \& Villee, 1977; McCormack \& Glasser, 1980), these cells might be susceptible to an inhibitory action of progesterone. On the other hand, if oestrogen receptors are also present in epithelial cells, these cells might not be susceptible to progesterone and could continue synthesizing protein. It will be necessary to describe the patterns of protein synthesis and cytosolic and nuclear receptors for oestrogen and progesterone in these two cell types to define the sites and mechanisms of action of the blastocyst.

In conclusion, this study has shown that the ovine blastocyst is capable of influencing endometrial function as early as Day 9 well before endocrine recognition of pregnancy on Day 12 (Moor, 1968) and implantation on Day 15 (Boshier, 1969). The success of embryo transfer up to Day 12 (Moor, 1968) suggests that these changes in endometrial function are not obligatory for the successful establishment of pregnancy or that they can still be activated by Day 12. The mechanism(s) by which the blastocyst brings about the changes in oestrogen receptor and protein synthesis remains unknown although it probably involves a local rather than a systemic effect.

The co-operation of the Director of the Animal Research Institute, Werribee and the assistance of Sue Wilson, Gail Matthews, Carmen Cocks and Kathy Burman is gratefully acknowledged. This project was supported by the Australian Wool Research Trust Fund and the Ford Foundation.

\section{References}

Bindon, B.M. (1971a) Systematic study of preimplantation stages of pregnancy in sheep. Aust. J. biol. Sci. 24, 131-147.

Bindon, B.M. (1971b) Role of progesterone in implantation in the sheep. J. Reprod. Fert. 24, 146, Abstr.

Boshier, D.P. (1969) A histological and histochemical examination of implantation and early placentome formation in sheep. J. Reprod. Fert. 19, 51-62.

Bradford, M.M. (1976) A rapid and sensitive method for the quantitation of microgram quantities of protein utilizing the principle of protein-dye binding. Analyt. Biochem. 72, 248-254.

Bullock, D.W. (1977) Steroids from the preimplantation blastocyst. In Development in Mammals, Vol. 2, pp. 199-208. Ed. M. H. Johnson. Elsevier/North Holland Biomedical Press, Amsterdam.

Burton, K. (1956) A study of the conditions and mechanisms of the diphenylamine reaction for the colorimetric estimation of deoxyribonucleic acid. Biochem. J. 62, 315-321.

Challis, J.R.G., Louis, T.M., Robinson, J.S. \& Thorburn, G.D. (1976) Progesterone and oestradiol in pituitary, brain and uterine tissues of the sheep. J. Endocr. 69, 451-452.

Clarke, I.J., Burman, K., Funder, J.W. \& Findlay, J.K. (1981) Estrogen receptors in the neuroendocrine tissues of the ewe in relation to breed, season, and stage of the estrous cycle. Biol. Reprod. 24, 323-331.

Cumming, I.A., Baxter, R.B. \& Lawson, R.A.S. (1974) Steroid hormone requirements for the maintenance of early pregnancy in sheep: a study using ovariectomized adrenalectomized ewes. J. Reprod. Fert. 40, 443-446.
Deaver, D.R. \& Guthrie, H.D. (1980) Cytoplasmic estrogen receptor, estradiol and progesterone concentrations in endometrium of nonpregnant and pregnant pigs. Biol. Reprod. 23, 72-77.

Ellinwood, W.E., Nett, T.M. \& Niswender, G.D. (1979) Maintenance of the corpus luteum of early pregnancy in the ewe. II. Prostaglandin secretion by the endometrium in vitro and in vivo. Biol. Reprod. 21, $845-856$.

Findlay, J.K. (1981) Blastocyst-endometrial interactions in early pregnancy in the sheep. J. Reprod. Fert. Suppl. 30. 171-182.

Findlay, J.K., Ackland, N., Burton, R.D., Davis, A.J., Maule Walker, F.M., Walters, D.E. \& Heap, R.B. (1981) Protein, prostaglandin and steroid synthesis in caruncular and intercaruncular endometrium of sheep before implantation. J. Reprod. Fert. 62, 361-377.

Gadsby, J.E., Heap, R.B. \& Burton, R.D. (1980) Oestrogen production by blastocyst and early embryonic tissue of various species. J. Reprod. Fert. 60 , 409-417.

Ginsburg, M., Greenstein, B.D., MacLusky, N.J., Morris, I.D. \& Thomas, P.J. (1974) An improved method for the study of high affinity steroid binding: oestradiol binding in brain and pituitary. Steroids 23, 773792.

Gottesman, M.M. (1978) Transformation-dependent secretion of a low molecular weight protein by murine fibroblasts. Proc. natn. Acad. Sci. U.S.A. 75, 2767-2771.

Greiss, F.C., Jr \& Anderson, S.G. (1970) Uterine blood flow during early ovine pregnancy. $A \mathrm{~m}$. J. Obstet. Gynec. 106, 30-38. 
Greiss, F.C. \& Miller, H.B. (1971) Unilateral control of uterine blood flow in the ewe. Am. J. Obstet. Gynec. 111, 299-301.

Hossain, M.I., Lee, C.S., Clarke, I.J. \& O'Shea, J.D. (1979) Ovarian and luteal blood flow, and peripheral plasma progesterone levels in cyclic guinea-pigs. $J$. Reprod. Fert. 57, 167-174.

Huckabee, W.E., Crenshaw, C., Curet, L.B., Mann, L. \& Barron, D.L. (1970) The effect of exogenous oestrogen on the blood flow and oxygen consumption of the uterus of the non-pregnant ewe. $Q$. Jl exp. Physiol. $55,16-24$.

Huslig, R.L., Fogwell, R.L. \& Smith, W.L. (1979) The prostaglandin forming cyclooxygenase of ovine uterus: relationship to luteal function. Biol. Reprod. 21, 589-600.

Koligian, K.B. \& Stormshak, F. (1977a) Nuclear and cytoplasmic estrogen receptors in ovine endometrium during the estrous cycle. Endocrinology 101, 524-533.

Koligian, K.B. \& Stormshak, F. (1977b) Progesterone inhibition of estrogen receptor replenishment in ovine endometrium. Biol. Reprod. 17, 412-416.

Lawson, R.A.S. \& Findlay, J.K. (1977) Embryomaternal interactions concerned with recognition of pregnancy. In Reproduction and Evolution, pp. 349-357. Eds J. H. Calaby \& C. H. Tyndale-Biscoe. Australian Academy of Science, Canberra.

Lewis, G., Wilson, L., Jr, Wilks, J.W., Pexton, J.E., Fogwell, R.L., Ford, S.P., Butcher, R.L., Thayne, W.V. \& Inskeep, E.K. (1977) PGF2 $\alpha$ and its metabolites in uterine and jugular venous blood and endometrium of ewes in early pregnancy. J. Anim. Sci. 45, 320-327.

Lewis, G.S., Jenkins, P.E., Fogwell, R.L. \& Inskeep, E.K. (1978) Concentrations of prostaglandins E2 and $F 2 \alpha$ and their relationship to luteal function in early pregnant ewes. J. Anim. Sci. 47, 1314-1323.

Logeat, F., Sartor, P., Vu Hai, M.T. \& Milgrom, E. (1980) Local effect of the blastocyst on estrogen and progesterone receptors in the rat endometrium. Science, N.Y. 207, 1083-1085.

Lowry, O.H., Rosebrough, N.J., Farr, A.L. \& Randall, R.J. (1951) Protein determination with the Folinphenol reagent. J. biol. Chem. 193, 265-275.

Marcus, G.J., Ainsworth, L. \& Lucis, R. (1979) Cholesterol biosynthesis and progesterone production by chorionic cells of the early sheep conceptus in vitro. Steroids 34, 295-304.

Martal, J. (1981) Control of luteal function during early pregnancy in sheep. J. Reprod. Fert. Suppl. 30, 201-210.

Martel, D. \& Psychoyos, A. (1981) Estrogen receptors in the nidatory sites of the rat endometrium. $\bar{S}$ cience, N.Y. 211, 1454-1455.

McCormack, S.A. \& Glasser, S.R. (1980) Differential response of individual uterine cell types from immature rats treated with estradiol. Endocrinology 106, 1634-1649.

Miller, B.G., Murphy, L. \& Stone, G.M. (1977) Hormone receptor levels and hormone, RNA and protein metabolism in the genital tract during the oestrous cycle of the ewe. J. Endocr. 73, 91-98.

Miller, B.G., Wild, J. \& Stone, G.M. (1979) Effects of progesterone on the oestrogen-stimulated uterus: a comparative study of the mouse, guinea pig, rabbit and sheep. Aust. J. biol. Sci. 32, 549-560.

Moor, R.M. (1968) Effect of embryo on corpus luteum function. J. Anim. Sci. 27, Suppl. 1, 97-118.

Roberts, G.P., Parker, J.M. \& Symonds, H.W. (1976) Macromolecular components of genital tract fluids from the sheep. J. Reprod. Fert. 48, 99-107.

Rowson, L.E.A. \& Moor, R.M. (1966) Development of the sheep conceptus during the first fourteen days. $J$. Anat. 100, 777-785.

Roy, E.J. \& McEwen, B.S. (1977) An exchange assay for estrogen receptors in cell nuclei in the adult rat brain. Steroids 30, 657-699.

Scatchard, G. (1949) The attractions of proteins for small molecules and ions. Ann. N.Y. Acad. Sci. 51, 660-672.

Shemesh, M., Milaguir, F., Ayalon, N. \& Hansel, W. (1979) Steroidogenesis and prostaglandin synthesis by cultured bovine blastocysts. $J$. Reprod. Fert. 56, 181-185.

Staples, L.D., Lawson, R.A.S. \& Findlay, J.K. (1978) The occurrence of an antigen associated with pregnancy in the ewe. Biol. Reprod. 19, 1076-1082.

Stone, G.M., Murphy, L. \& Miller, B.G. (1978) Hormone receptor levels and metabolic activity in the uterus of sheep: regulation by estradiol and progesterone. Aust. J. biol. Sci. 31, 395-403.

Stone, G.M., Wild, J. \& Miller, B.G. (1979) The uterine endometrium and isthmic oviduct in the ewe: does progesterone act as an antiestrogen? Biol. Reprod. 21, 273-280.

Talley, T.J., Tobert, J.A., Armstrong, E.G. \& Villee, C.A. (1977) Changes in estrogen receptor levels during deciduomata development in the pseudopregnant rat. Endocrinology 101, 1538-1544.

Received 7 April 1981 